\title{
ASAS FUNGSI SOSIAL HAK ATAS TANAH PADA NEGARA HUKUM (SUATU TINJAUAN DARI TEORI, YURIDIS DAN PENERAPANNYA DI INDONESIA)
}

\author{
Triana Rejekiningsih \\ Fakultas Keguruan dan Ilmu Pendidikan Universitas Sebelas Maret \\ Email : triana_rizq@staff.uns.ac.id
}

\begin{abstract}
The objective of this study is to investigate the nature of the social function principles of land rights within the theoretical and juridical perspective and its implementation in Indonesia. This research uses the sociological or empirical research method to view the effectiveness of law in society. The result of research shows that the nature of social function principles of land rights theoretically is an acknowledgement of individual, social, and public interests in lands. The juridical basis of the social function principles of land rights refered to Article 6 of Law Number 5 of 1960 regarding Basic Regulations for Agrarian Affairs as constitutionally mandated which affirms the land protection for its people's greatest possible welfare. The social function principles are materialized in various law norms that are land reform, land consolidation, land redistribution, abandoned land controlling, and land provision for public interest. The government through the National Land Agency controls land affairs as to protect its citizens' land rights. The implementation of the social function principles of land rights is also done through the community empowerment program, namely: Pokmasdartibnah (community groups which are aware of land affairs) established by the National Land Agency and participation through Consortium Agrarian Reform, which establishes Damara (Advanced Land Reform) villages.

Keywords: Social function principles, theory, implementation
\end{abstract}

\begin{abstract}
Abstrak
Artikel ini bertujuan untuk mengetahui hakekat asas fungsi sosial atas tanah baik dalam tinjauan teori, yuridis, dan penerapannya di Indonesia. Penelitian hukum ini bersifat sosiologis atau empiris untuk melihat efektivitas hukum di masyarakat. Hasil Penelitian menunjukkan, bahwa asas fungsi sosial hak atas tanah secara teori merupakan pengakuan atas kepentingan perorangan, kepentingan sosial dan kepentingan umum atas tanah. Landasan yuridis asas fungsi sosial hak atas tanah, didasarkan pada Pasal 6 Undang-Undang Nomor 5 tahun 1960 tentang Pokok-Pokok Agraria sebagai amanah konstitusi tentang pentingnya perlindungan tanah bagi sebesar-besar kemakmuran rakyat. Asas fungsi sosial hak atas tanah diwujudkan dalam berbagai norma hukum, tentang landreform, konsolidasi tanah, redistribusi tanah, penertiban tanah-tanah terlantar, dan pengadaan tanah untuk kepentingan umum. Pemerintah melalui BPN, melakukan pengendalian pertanahan untuk memberikan perlindungan hak-hak warga negara atas tanah. Penerapan asas fungsi sosial hak atas tanah juga dilakukan melalui program pemberdayaan masyarakat dengan membentuk Pokmasdartibnah (Kelompok Masyarakat Sadar Tertib Pertanahan) oleh BPN, dan
\end{abstract}


adanya partisipasi Konsorsium Pembaharuan Agraria (KPA) membentuk Desa Maju Reforma Agraria (Damara).

Kata Kunci : asas fungsi sosial hak atas tanah, teori, penerapan

\section{A. Pendahuluan}

Negara Indonesia ialah negara hukum, ketentuan ini dijamin dalam UndangUndang Dasar Negara Republik Indonesia Tahun 1945 (UUD NRI Tahun 1945), pada Pasal 1 ayat (3). Sebagai negara hukum Indonesia memiliki kewajiban untuk melindungi segenap rakyat Indonesia, termasuk mengatur kemanfaatan semua aspek kehidupan agar mampu memberikan kemakmuran bagi seluruh rakyat Indonesia. Negara hukum Indonesia didasarkan pada konsep negara kesejahteraan (walfare state), yang bertujuan untuk sebesar-besar kemakmuran rakyat. Hal ini merupakan amanah konstitusi pada Pasal 33 ayat (3) yang menyatakan bahwa, "bumi, air dan kekayaan alam yang terkandung di dalamnya dikuasai oleh negara untuk sebesar-besar kemakmuran rakyat". Tujuan negara kesejahteraan (welfare state) untuk menjamin hak-hak warga negara pada era modern sekarang ini, memiliki ketergantungan pada ketersediaan sumber daya alam. Kondisi ketersediaan sumber daya alam menjadi faktor yang menentukan dalam memenuhi hak-hak dasar warga negara.

Salah satu sumber daya alam yang sangat penting dalam menjamin kesejahteraan dalam negara hukum Indonesia di era globalisasi sekarang ini adalah tanah. Keberadaan tanah menjadi sumber daya alam yang penting bagi negara Indonesia, yang diatur dalam Undang-Undang Nomor 5 Tahun 1960 tentang Peraturan Dasar Pokok-Pokok Agraria (UUPA), pada Pasal 1 ayat (1) menyatakan bahwa, "semua tanah dalam wilayah Negara Indonesia adalah tanah bersama dari seluruh rakyat Indonesia”. Selanjutnya dalam Pasal 6 UUPA menyatakan bahwa, "Semua hak atas tanah mempunyai fungsi sosial". Pasal tersebut selanjutnya dinyatakan sebagai salah satu asas hukum tanah yang diistilahkan asas fungsi sosial hak atas tanah. Keberadaan asas fungsi sosial hak atas tanah dalam hukum tanah menjadi landasan fundamental bagi terwujudnya tanah yang bermanfaat bagi sebesar-besar kemakmuran rakyat di negara kesejahteraan.

Keberfungsian norma hukum agar berfungsi mengikat harus didasarkan pada asas hukum. Asas hukum membentuk isi norma hukum yang dirumuskan dalam peraturan hukum. Tanpa mengetahui asas hukum tidak akan mungkin dapat 
memahami hakikat hukum. Oleh karena itu untuk memahami hukum suatu bangsa harus menggali asas-asas hukumnya. (Rahardjo, Satjipto. 2000, dalam Erwin, Muhamad. 2011: 50)

Astim Riyanto menegaskan, bahwa agar hukum mewujudkan ketertiban hukum, kepastian, dan perlindungan hukum, maka asas-asas-asas hukum/asasasas peraturan perundang-undangan dan norma-norma (kaidah-kaidah) hukum yang menjadi pemasti hukum harus mengandung kepastian.

Terkait dengan keberadaan asas fungsi sosial hak atas tanah pada negara hukum sebagai salah satu asas hukum agraria, memiliki peran yang sangat penting dalam mewujudkan tujuan negara dalam konsep welfare state seperti Indonesia. Terkandung makna dalam asas fungsi sosial hak atas tanah, adanya pemenuhan hak atas tanah untuk sebesar-besar kemakmuran rakyat sebagaimana ketentuan dalam konstitusi UUD NRI Tahun 1945.

Namun, dalam perkembangannya tanah sebagai sumber daya agraria belum terjamin dan terpelihara kemanfaatannya untuk memenuhi kemakmuran rakyat. Keberadaan tanah belum mampu memenuhi kemanfaatan bersama dalam konsep fungsi sosial hak atas tanah. Salah satu persoalan yang saat ini muncul terkait dengan pemenuhan kebutuhan bersama seluruh rakyat dalam konsep fungsi sosial yakni ketersediaan tanah pertanian untuk pemenuhan kebutuhan pangan. Mengutip tulisan dari Yayasan AKATIGA (Maguantara, Y. N. 2005: 26), menyatakan bahwa "Di negara-negara agraris seperti Indonesia, penyebab kemiskinan dan kurang pangan yang utama adalah rendahnya akses penduduk pedesaan terhadap tanah.”.

Kondisi tersebut diatas banyak dialami pada daerah-daerah yang memiliki potensi sebagai daerah agraris yang tanahnya sangat produktif untuk menghasilkan produksi pertanian. Salah satu daerah penghasil padi yang tanahnya memiliki potensi agraris adalah di Kabupaten Sukoharjo, Propinsi Jawa Tengah. Kabupaten Sukoharjo memiliki luas wilayah keseluruhan sebesar 46.666 Ha atau 466,66 $\mathrm{Km}^{2}$, sekitar 1,43\% luas wilayah Propinsi Jawa Tengah. Menurut data penggunaan tanah, terdiri dari tanah sawah sebesar 45,12\% (21.054 Ha) dan tanah bukan sawah 54,885 \% (25.612 Ha). Pada tahun 2012 luas tanah sawah di Kabupaten Sukoharjo seluas 21.054 Ha padahal sebelumnya pada tahun 2010 luas lahan sawah sebesar $21.287 \mathrm{Ha}$, mengalami penurunan atau pengurangan sebesar 
1\%. Kondisi ini memperlihatkan terjadinya alih fungsi lahan sawah ke tanah bukan sawah di Kabupaten Sukoharjo sebesar 1\% dari tahun 2010 sampai 2012. Jumlah penduduk yang bekerja di Kabupaten Sukoharjo didominasi oleh tiga sektor, yaitu sektor perindustrian sebesar $27,04 \%$ (122.170 orang), sektor perdagangan sebesar $25,33 \%$ (110.832 orang) dan sektor pertanian sebesar 18,95\% (51.154 orang). Dari data tersebut dapat diketahui, penduduk yang bekerja dalam sektor pertanian paling sedikit diantara sektor yang lain. Keadaan ini menyebabkan Kabupaten Sukoharjo mengalami penurunan produksi pertaniannya. Hal ini bisa diketahui dari data produktivitas pertanian padi sawah di Kabupaten Sukoharjo yang pada kurun waktu 3 (tiga) tahun terakhir mengalami penurunan. Hasil produksi pertanian padi pada tahun 2010 sebesar 283.655 ton, tahun 2011 hasil produksi 269.472 ton, terjadi penurunan produksi cukup besar pada tahun 2011 yaitu sebesar 5\%.

Penyusutan luas tanah pertanian saat ini sangat mengancam kehidupan bangsa, karena berdampak pada ketersediaan pemenuhan kebutuhan pangan sebagai kebutuhan bersama dalam konsep fungsi sosial atas tanah, untuk sebesarbesar kemakmuran rakyat di negara yang berpotensi agraris. Potensi kehidupan agraris yang seharusnya mampu meningkatkan kemakmuran rakyat menjadi tidak termanfaatkan bahkan berpotensi terpinggirkan. Hilangnya karakteristik masyarakat agraris berdampak pada terjadinya risk society atau resiko kewarganegaraan pada negara-negara yang memiliki potensi sebagai negara agraris seperti Indonesia. Fenomena yang terjadi di Kabupaten Sukoharjo tersebut, berdampak pada hilangnya identitas kewarganegaraan sebagai negara yang berpotensi agraris. Bangsa menjadi tidak mandiri sebagai negara agraris, tergantung pada negara lain dan tidak memiliki kedaulatan pangan.

Pada kondisi yang lain seringkali tanah yang telah berubah fungsi menjadi non pertanian tersebut hanya dimanfaatkan untuk kepentingan pribadi saja tanpa memperhatikan kepentingan masyarakat yang lain, bahkan apabila pemerintah menetapkan tanah dibutuhkan untuk kepentingan umum tidak merelakannya. Muncul berbagai perilaku yang menunjukkan ketamakan, keserakahan, tidak memiliki solidaritas, dan tidak peduli dalam memanfaatkan. Perilaku tersebut berdampak pada terjadinya konflik atas tanah yang menimbulkan kesenjangan dan 
ketidakadilan dalam penguasaan tanah yang berujung pada perbenturan antara kepentingan perorangan, kepentingan sosial dan kepentingan umum atas tanah.

Menurut rekaman konflik yang dilakukan oleh Konsorsium Pembaharuan Agraria (KPA) sepanjang tahun 2013 terdapat 369 konflik agraria dengan luasan mencapai 1.281.660.09 hektar (Ha) dan melibatkan 139.874 Kepala Keluarga (KK). Dari catatan KPA, selama lima tahun terakhir sejak tahu 2009 sampai dengan 2013, telah terjadi peningkatan jumlah konflik sebanyak $314 \%$ (persen) atau 3 (tiga) kali lipat, terjadi peningkatan luasan areal konflik sebanyak $861 \%$ (persen), dan jumlah kepala keluarga yang terlibat konflik juga meningkat 1.744 $\%$ (persen) dibandingkan 2009.

Hasil observasi penelitian pada daerah yang mengalami konflik tanah, yakni di Desa Pasawahan, Kecamatan Banjarsari, Kabupaten Ciamis, Provinsi Jawa Barat, diketahui sejak tahun 2002 terjadi konflik atas tanah perkebunan, seluas 260 Ha. Berdasarkan data Potensi Desa, diketahui sebagian besar petani yaitu sebanyak 800 keluarga atau sekitar 52,29\% memiliki lahan yang sempit, sedangkan yang memiliki lahan luas hanya 248 keluarga atau sekitar 16,21\%. Selebihnya tidak memiliki lahan sejumlah 482 keluarga atau sekitar 31,5\%. Desa Pasawahan merupakan daerah konflik pertanahan yang terjadi akibat adanya pemberian ijin penguasaan tanah dengan status Hak Guna Usaha (HGU) perkebunan yang diberikan pada PT Cipicung, di atas tanah yang selama ini diyakini menjadi kepemilikan masyarakat sejak nenek moyang mereka dengan ikatan masyarakat adat. Akibat dari konflik tersebut, terjadi perilaku yang saling berbenturan kepentingan, baik antara perusahaan dengan petani, maupun petani dengan pemerintah sebagai pemberi ijin, yang melibatkan kurang lebih $200 \mathrm{KK}$ atau 400 petani. Petani sebagai bagian dari warga negara merasa tidak terpenuhi hak-haknya akibat tidak memiliki akses atas tanah pertanian dan perkebunan, yang dijadikan sebagai sumber penghidupan bersama. Petani melakukan gerakan dengan menguasai tanah sengketa dengan melakukan reclaiming, yang bertujuan untuk merebutkan kembali tanah rakyat.

Fenomena yang terjadi pada kedua daerah yakni di Kabupaten Sukoharjo dan Kabupaten Ciamis tersebut diatas, menunjukkan belum mampunya tanah dimanfaatkan oleh seluruh rakyat yang menjamin rasa keadilan bagi sebesar-besar 
kemakmuran rakyat, sebagaimana makna yang terkandung dalam asas fungsi sosial hak atas tanah.

Secara fundamental asas fungsi sosial hak atas tanah bertujuan menjamin kemanfaatan tanah bagi sebesar-besar kemakmuran rakyat. Sebagai negara hukum yang berkonsepsi negara kesejahteraan berdasarkan Pancasila, maka pemanfaatan tanah harus menjamin rasa keadilan bagi seluruh rakyat. Penerapan asas fungsi sosial hak atas tanah menjadi strategi bagi terwujudnya negara hukum yang menjamin pemanfaatan tanah yang berkeadilan. Untuk itu sangat penting melakukan pengkajian tentang hakekat asas fungsi sosial baik dalam tinjauan teori, yuridis, dan penerapannya di Indonesia, sebagai upaya strategis untuk memenuhi hak-hak atas tanah bagi sebesar-besar kemakmuran rakyat.

Berdasarkan latar belakang yang diuraikan di atas, maka permasalahan yang akan diteliti dalam artikel ini adalah bagaimana penerapan Asas Fungsi Sosial Hak Atas Tanah di Indonesia?

\section{B. Metode Penelitian}

Berdasarkan latar belakang penelitian tersebut diatas maka penelitian ini bisa dikategorikan merupakan jenis penelitian hukum. Penelitian hukum pada hakekatnya merupakan penelitian ilmu-ilmu sosial, yang menurut Mohamad Hasyim (Suratman, dan Dillah, Phillips. 2013: 51) memasukkan penelitian hukum kedalam penggolongan termasuk ke dalam bagian dan bidang ilmu sosial. Penelitian hukum ini bersifat sosiologis atau empiris untuk melihat efektivitas hukum di masyarakat. Penelitian ini diistilahkan dengan socio legal research, yaitu perpaduan antara legal research dan social research. Penggunaan pendekatan ini dimaksudkan untuk memahami hubungan dan keterkaitan antara aspek-aspek hukum, dengan realitas dalam masyarakat.

Populasi dalam penelitian ini adalah subyek yang berkaitan dengan penerapan asas fungsi sosial hak atas. Secara khusus, penelitian ini menggunakan purposive or judgemental sampling atau snowball sampling. Subyek penelitian antara lain (1) Wakil Ketua Komisi II DPR RI, Ganjar Pranowo (Sekarang Gubernur Jawa Tengah); (2) Kasubag Tata Usaha Deputi IV BPN RI, Bidang Pengendalian Pertanahan dan Pemberdayaan Masyarakat Shamy Ardian, S.T., M.Eng; (3) Penyelidik Senior Komisi Nasional Hak Asasi Manusia RI, Husendro, 
SH., M.H; (4) Sekretaris Jenderal (Sekjen) Konsorsium Pembaharuan Agraria (KPA), Iwan Nurdin; dan (5) Wasekjen KPA Dewi Kartika.

\section{Hasil Penelitian dan Pembahasan}

\section{Hakekat Asas Fungsi Sosial Hak Atas Tanah dalam Tinjauan Teori}

Asas fungsi sosial hak atas tanah berasal dari teori fungsi sosial hak atas tanah yang dikemukakan oleh ahli hukum Perancis Leon Duguit. Awalnya teori ini muncul akibat adanya upaya untuk menentang konsep liberal klasik yang berkembang saat itu. Konsep liberal klasik mendominasi konsep politik dan hukum modern. Menurut Sheila R. Foster dan Daniel Bonilla dalam artikelnya pada Symposium The Social Function of Property : A Comparative Law Perspective yang diselenggarakan Fordham University Scholl of Law di New York, pada tanggal 15 November 2011 (Sheila R. Foster dan Daniel Bonilla, 2011: 101) menyatakan bahwa, konsepsi liberal klasik berkaitan dengan kepemilikan properti atau hak kepemilikan tanah mendominasi pemikiran hukum dan politik modern. Gagasan yang berkembang dari kosenp tersebut bahwa kepemilikan hak atas tanah adalah hak subyektif dan sifatnya mutlak. Pada umumnya warga masyarakat, politisi, dan akademisi beranggapan bahwa kepemilikan hak atas tanah sebagai hak individu yang hanya dibatasi oleh hak orang lain dan kepentingan umum. Oleh karena itu, pemegang hak dapat menggunakan, memperoleh manfaat, dan menggunakan asetnya tersebut dengan cara yang tepat, sesuai dengan tatanan hukum dan tidak melanggar kepentingan umum. Apalagi hak ini sangat penting untuk pelaksanaan otonomi atau kebebasan individu. Kepemilikan hak atas tanah atau properti memungkinkan dan mencerminkan keputusan yang dibuat oleh individu sehubungan dengan rencana hidup mereka. Tanah merupakan sarana fisik yang memungkinkan orang untuk membangun identitas mereka dan mengekspresikan komitmen moral mereka. Antara hak individu dan tanah saling memiliki hubungan yang berkaitan satu dengan yang lain. Akibatnya, konsep liberal klasik tentang hak atas tanah membebankan kewajiban antara negara dan individu .

Konsep liberal klasik ini dikritik oleh perspektif teoritis yang beragam seperti liberalisme egaliter, sosialisme, dan komunisme. Bahwa konsepsi liberal klasik tidak lengkap atau tidak adil. Kritik menunjukkan, misalnya, bahwa konsep kepemilikan benda menurut liberal klasik mengaburkan kewajiban dan hubungan 
antara subjek sebagai pemilik dengan masyarakat, atau mereka menekankan konsekuensi negatif bahwa hak ini dikategorikan sebagai bagian dari kekayaan. Pada tingkat normatif, lawan dari konsep hak atas tanah menurut liberal klasik menawarkan berbagai alternatif, dari penghapusan kepemilikan pribadi atas alatalat produksi melalui intervensi pemerintah yang kuat dalam hak atas kekayaan dengan tujuan untuk tercapainya redistribusi tanah (Foster, Sheila R. \& Daniel Bonilla. 2011: 102).

Gagasan tersebut selanjutnya memunculkan konsep alternatif yang paling memberikan keyakinan dan berpengaruh pada abad ke dua puluh, yakni fungsi sosial hak atas tanah atau dikenal dengan istilah the social function of property dalam berbagai literatur yang ditemukan oleh peneliti. Fungsi sosial hak atas tanah didasari teori yang dikembangkan pertama kali oleh Leon Duguit pada tahun 1922. Duguit berpendapat bahwa properti atau dikenal dengan kepemilikan hak atas tanah bukan merupakan hak tapi lebih dari itu merupakan fungsi sosial. Pemilik memiliki kewajiban sehubungan dengan fungsi sosialnya sehingga tidak bisa hanya melakukan apa yang dia inginkan saja atas properti miliknya. Dijelaskan lagi bahwa pemilik wajib menjadikan tanah hak miliknya menjadi produktif dan diletakkan demi pelayanan untuk masyarakat melalui kegiatan ekonomi. Ide fungsi sosial dari properti atau lebih dikenal dengan fungsi sosial hak atas tanah berdasarkan deskripsi realitas sosial mengakui solidaritas sebagai salah satu fondasi utamanya. Akibatnya, negara harus melindungi tanah hanya jika memenuhi fungsi sosialnya. Ketika pemilik tidak bertindak dengan cara yang konsisten dengan kewajibannya, negara harus melakukan intervensi untuk mendorong atau menghukumnya (Foster \& Bonila. 2011: 103).

Menurut teori fungsi sosial ini, hak adalah fungsi sosial dalam arti bahwa kekuasaan yang dimiliki seseorang dibatasi oleh kepentingan masyarakatnya (Rasjidi, Lili, dkk. 2002: 120). Dalam konsep fungsi sosial tidak ada hak subyektif (subyektief recht), namun yang ada adalah hanya fungsi sosial (Parlindungan. 1998: 65).

Senada dengan dua konsep teori fungsi sosial tersebut diatas, Notonagoro menegaskan bahwa hak milik yang memiliki fungsi sosial itu sebenarnya mendasarkan atas diri individu, mempunyai dasar yang individualistis lalu ditempelkan kepadanya sifat yang sosial, sedangkan jika berdasarkan Pancasila 
hukum kita tidak berdasarkan atau corak individualistis, tetapi bercorak dwi tunggal. Kepentingan masyarakat dan perseorangan haruslah saling imbang untuk mengimbangi dwi tunggal. Dengan kata lain, di dalam hak milik tercantum sifat diri dan disamping itu memiliki sifat kolektif. Jadi, bukan sifat hak milik privat perorangan yang memiliki sifat kolektif atau melepaskan sifat individunya. (Notonagoro. 1992: 51, dalam Bernhard Limbong. 2011: 122-123)

Konsep kepentingan dapat dirujuk dari teori kepentingan menurut Roscou Pound, yang mengklasifikasikan kepentingan dalam tiga jenis, antara lain : (1) kepentingan individual (pibadi); (2) kepentingan umum; (3) kepentingan sosial. Pendapat tersebut disertai penegasan lebih lanjut, bahwa kepentingan individu berasal dari sudut urusan pribadi, domestik, dan hak milik. Sedangkan kepentingan umum dengan tujuan khusus untuk kepentingan negara sebagai lembaga hukum dan sebagai penjaga kepentingan sosial (Nobleman, Eli, E. 1961: 195-196, http://www.wcl.american.edu/journal/lawrev/10/nobleman.pdf, dikutip pada 26 Mei 2014)

Selanjutnya, berkaitan dengan fungsi hak dapat dirujuk pendapat dari Carl Wellman, yang menyatakan fungsi suatu hak adalah untuk mengatasi konflik dengan memberikan prioritas hukum bagi keinginan dan keputusan suatu pihak di atas keinginan dan keputusan pihak lain. Hak hukum adalah alokasi suatu ruang kebebasan dari kontrol kepada pemilik hak agar leluasa menentukan keputusankeputusan yang efektif di dalam wilayah yang ditetapkan tersebut (Nickel, James. 1996: 19-21).

Pandangan Carl Wellman tersebut dapat diambil makna, bahwa, fungsi hak berhubungan dengan pengakuan atas kepentingan pribadi atau perorangan yang memberikan kewenangan kebebasan bertindak. Sedangkan fungsi suatu hak hukum untuk memberikan kewenangan terkait dengan kepemilikan sesuatu agar dapat dipergunakan dalam batas-batas yang ditentukan oleh hukum (otoritas).

Selain itu patut dirujuk pula pendapat dari Martin Dixon yang menyatakan, bahwa tanah merupakan asset fisik dan merupakan hak. Tanah mengandung kekhususan yakni harus memenuhi kebutuhan dalam kehidupan sosial, yang mengandung makna adanya sistem hukum tanah yang berfungsi untuk menjamin kemanfaatan tanah untuk kepentingan bersama. Pendapat tersebut diperkuat Maria S.W. Sumardjono (2007, hlm. 4) yang menegaskan keberadaan tanah sebagai 
social asset dan capital asset. Sebagai social asset tanah merupakan sarana pengikat kesatuan sosial dikalangan masyarakat untuk hidup dan berkehidupan, sedangkan capital asset, tanah merupakan faktor modal dalam pembangunan dan telah tumbuh sebagai benda ekonomi yang sangat penting sekaligus sebagai bahan perniagaan dan obyek spekulasi. (Rubaie, Achmad. 2007: 1)

Secara teori, asas fungsi sosial hak atas tanah mengandung pengakuan adanya kepentingan perorangan, kepentingan sosial, dan kepentingan umum atas tanah. Asas fungsi sosial hak atas tanah memberi kewenangan kepada pemilik hak untuk mempergunakan kepemilikan atas tanah dalam batas-batas yang ditentukan oleh hukum, dengan memperhatikan kepentingan masyarakat dan negara. Kepemilikan atas tanah bukan hanya merupakan hak tapi lebih dari itu merupakan fungsi sosial. Kondisi ini memunculkan konsekuensi adanya hak dan kewajiban pemegang hak atas tanah dalam memanfaatkan tanah. Selain itu negara berkewajiban untuk melindungi tanah sebagai social asset dan capital asset untuk sebesar-besar kemakmuran rakyat

\section{Landasan Yuridis Asas Fungsi Sosial Hak Atas Tanah di Indonesia}

Asas fungsi sosial hak atas tanah merupakan salah satu asas yang menjadi dasar dalam menerapkan hukum agraria di Indonesia. Secara yuridis asas fungsi sosial hak atas tanah diatur dalam Undang-Undang Pokok-Pokok Agraria Nomor 5 Tahun 1960 tentang Peraturan Dasar Pokok-Pokok Agraria (UUPA), pada Pasal 6 yang menyatakan bahwa "Semua hak atas tanah mempunyai fungsi sosial".

Selanjutnya menurut Penjelasan Umum UUPA pada huruf A, angka romawi II tentang Dasar-dasar Hukum Agraria Nasional, khususnya angka (4) menyatakan :

Dasar yang keempat diletakkan dalam pasal 6, yaitu bahwa "Semua hak atas tanah mempunyai fungsi sosial". Ini berarti, bahwa hak atas tanah apapun yang ada pada seseorang, tidaklah dapat dibenarkan, bahwa tanahnya itu akan dipergunakan (atau tidak dipergunakan) semata-mata untuk kepentingan pribadinya, apalagi kalau hal itu menimbulkan kerugian bagi masyarakat. Penggunaan tanah harus disesuaikan dengan keadaannya dan sifat daripada haknya, hingga bermanfaat baik bagi kesejahteraan dan kebahagiaan yang mempunyainya maupun bermanfaat bagi masyarakat dan Negara. Tetapi dalam pada itu ketentuan tersebut tidak berarti, bahwa kepentingan perseorangan akan terdesak sama sekali oleh kepentingan umum (masyarakat). Undang-Undang Pokok-Pokok Agraria memperhatikan pula kepentingan-kepentingan perseorangan. Kepentingan masyarakat dan 
kepentingan perseorangan haruslah saling mengimbangi, hingga pada akhirnya akan tercapailah tujuan pokok : kemakmuran, keadilan dan kebahagiaan bagi rakyat seluruhnya (pasal 2 ayat 3). Berhubung dengan fungsi sosialnya, maka adalah suatu hal yang sewajarnya bahwa tanah itu harus dipelihara baik-baik, agar bertambah kesuburannya serta dicegah kerusakannya. Kewajiban memelihara tanah ini tidak saja dibebankan kepada pemiliknya atau pemegang haknya yang bersangkutan, melainkan menjadi beban pula dari setiap orang, badan hukum atau instansi yang mempunyai suatu hubungan hukum dengan tanah itu (pasal 15). Dalam melaksanakan ketentuan ini akan diperhatikan kepentingan fihak yang ekonomis lemah.

Pasal 6 Undang-Undang Nomor 5 Tahun 1960 tentang Pokok-Pokok Agraria (UUPA) menegaskan bahwa semua hak atas tanah mempunyai fungsi sosial, hal ini merupakan pencerminan dari ketentuan Pasal 33 ayat (3) UUD NRI Tahun 1945 sebagai ketentuan yang menegaskan pentingnya perlindungan atas bumi, air dan kekayaan alam termasuk didalamnya pengertian tanah bagi sebesarbesar kemakmuran rakyat. Secara yuridis kedua ketentuan tersebut mengandung makna yang secara eksplisit saling berhubungan, bahwa tanah dalam pemahaman fungsi sosial harus dilindungi keberadaannya agar dapat memberikan kemakmuran bagi seluruh rakyat. Hal ini mengandung kewajiban bagi seluruh rakyat dalam memanfaatkan tanah tidak hanya mementingkan kepentingan pribadinya saja namun juga harus memperhatikan kepentingan masyarakat maupun kepentingan umum. Kewajiban memberikan perlindungan atas tanah dilakukan oleh negara untuk kepentingan kemakmuran seluruh rakyat. Maka menjadi kewajiban seluruh rakyat dibawah kekuasaan negara dalam memanfaatkan tanah harus dengan sebaik-baiknya, tanpa menghilangkan potensi tanah sebagsi sumber daya kehidupan bersama.

Meskipun frasa " fungsi sosial" ini tidak disebutkan secara eksplisit dalam UUD NRIT 1945, namun secara implisit ayat ini harus ditafsirkan bahwa fungsi sosial dari hak milik diartikan sebagai hak milik yang tidak boleh dibiarkan merugikan kepentingan masyarakat umum (Parlindungan, 1991: 65).

Asas fungsi sosial hak atas tanah dalam hukum tanah nasional, mengandung makna bahwa hak atas tanah apa pun yang ada pada seseorang, tidak dapat dibenarkan bahwa tanahnya itu akan dipergunakan (atau tidak dipergunakan) semata-mata untuk kepentingan pribadinya, apalagi kalau hal itu menimbulkan kerugian bagi masyarakat. Penggunaan tanah harus disesuaikan dengan keadaannya 
dan sifat daripada haknya, sehingga bermanfaat, baik bagi kesejahteraan dan kebahagiaan yang mempunyainya maupun bagi masyarakat dan negara. Akan tetapi dalam konteks itu, ketentuan tersebut tidak berarti bahwa kepentingan perseorangan akan terdesak sama sekali oleh kepentingan umum dan kepentingan masyarakat. UUPA memperhatikan pula kepentingan-kepentingan perseorangan.

Kewenangan setiap orang atas hak milik dijamin dalam UUD NRI Tahun 1945, pada Pasal 28 H ayat (4) yang menyatakan bahwa "Setiap orang berhak mempunyai hak milik pribadi dan hak milik tersebut tidak boleh diambil alih secara sewenang-wenang oleh siapa pun". Ketentuan tersebut merupakan penegasan dari Pasal 33 ayat (3) UUD NRI Tahun 1945 terkait dengan hak kepemilikan rakyat Indonesia atas bumi, air ruang angkasa dalam batas-batas yang ditentukan untuk sebesar-besar kemakmuran rakyat. Termasuk dalam pemahaman ini adalah hak-hak atas tanah khususnya hak milik atas tanah.

Pengakuan hak milik sebagai bagian dari hak asasi manusia dijamin juga dalam Undang-Undang Nomor 39 Tahun 1999 tentang Hak Asasi Manusia (UU HAM) pada Pasal 36, ayat (1) yang menyatakan bahwa "Setiap orang berhak mempunyai milik, baik sendiri maupun bersama-sama dengan orang lain demi pengembangan dirinya, keluarga, bangsa dan masyarakat dengan cara tidak melanggar hukum"; ayat (2) “Tidak seorang pun boleh dirampas miliknya dengan sewenang-wenang dan secara melawan hukum"; (3) "Hak milik mempunyai fungsi sosial". Ketentuan tersebut mengandung makna, bahwa hak milik merupakan hak setiap warga negara dalam memenuhi kebutuhannya. Hak milik keberadaannya dilindungi oleh hukum, namun juga dibatasi dengan fungsi sosial. Ketentuan ini ditegaskan dalam pasal 37 ayat (1) UU HAM, bahwa "Pencabutan hak milik atas suatu benda demi kepentingan umum, hanya diperbolehkan dengan mengganti kerugian yang wajar dan segera serta pelaksanaannya sesuai dengan ketentuan peraturan perundang-undangan"; ayat (2) "Apabila sesuatu benda berdasarkan ketentuan hukum demi kepentingan umum harus dimusnahkan atau tidak diberdayakan baik untuk selamanya maupun untuk sementara waktu, maka hal itu dilakukan dengan mangganti kerugian sesuai dengan ketentuan perundangundangan kecuali ditentukan lain”.

Fungsi sosial hak atas tanah ditegaskan pula dalam Undang-Undang Nomor 11 Tahun 2005 tentang Pengesahan International Covenant on Economic, Social, 
and Cultural Rights (Kovenan Internasional tentang Hak-hak Ekonomi, Sosial, dan Budaya). Pasal 11 ayat (1) menyebutkan tentang "hak setiap orang atas standar kehidupan yang layak bagi diri sendiri dan keluarganya, termasuk hak untuk memperoleh pangan, sandang dan perumahan, dan atas perbaikan kondisi hidup secara terus-menerus". Selanjutnya dalam ayat (2) ditegaskan tentang "pengakuan terhadap hak mendasar dari setiap orang untuk bebas dari kelaparan, dan untuk mendukung hak itu negara harus mengambil langkah-langkah yang diperlukan untuk meningkatkan cara-cara produksi, konsumsi dan distribusi pangan sehingga mencapai perkembangan dan pemanfaatan sumber daya alam yang efisien".

UUPA diterbitkan dalam rangka mewujudkan amanah Pasal 33 ayat (3) UUD NRI Tahun 1945, merupakan kenyataan hukum dalam menjelaskan tujuan dari tanah sebagai social asset dan capital asset. Sebagai undang-undang nasional ketentuan yang termuat dalam pasal-pasal UUPA merupakan perwujudan dari sila-sila dalam Pancasila. (Sumardjono, Maria S.W. 2007: 4)

Eksistensi tanah dalam kehidupan manusia mempunyai arti dan sekaligus memiliki fungsi ganda, yaitu sebagai social asset dan capital asset. Sebagai social asset tanah merupakan sarana pengikat kesatuan sosial dikalangan masyarakat untuk hidup dan berkehidupan, sedangkan capital asset, tanah merupakan faktor modal dalam pembangunan dan telah tumbuh sebagai benda ekonomi yang sangat penting sekaligus sebagai bahan perniagaan dan obyek spekulasi. (Rubaie, Achmad, 2007: 1)

Keberadaan fungsi sosial hak atas tanah tersebut dalam UUPA sebagai sumber utama Hukum Tanah Nasional, dimana fungsi sosial hak atas tanah merupakan salah satu dari 3 (tiga) kewajiban dalam UUPA yang bersifat umum yang dibebankan pada setiap pemegang hak atas tanah, yakni : (a) kewajiban menjalankan fungsi sosial hak atas tanah (Pasal 6); (b) kewajiban memelihara tanah (Pasal 52 ayat (1)); (c) kewajiban untuk mengerjakan sendiri secara aktif tanah pertanian (Pasal 10). (Sitorus, Oloan, 2006:79)

Ditinjau dari landasan yuridis asas fungsi sosial hak atas tanah menjadi dasar untuk memberikan kepastian dan perlindungan tanah, agar dalam memanfaatkan serta tidak memanfaatkan tanah, tidak boleh semata-mata untuk kepentingan pribadi, apalagi sampai merugikan pihak lain. Hal ini dimaksudkan, 
bukan berarti subyek hak yang melaksanakan fungsi sosial akan kehilangan hak atas tanahnya, akan tetapi disini dimaksudkan ada keseimbangan antara kepentingan perorangan, kepentingan sosial, dan kepentingan umum atas tanah. Hak atas tanah yang dimiliki seseorang tidak boleh digunakan semata-mata untuk kepentingan pribadi atau perseorangan, melainkan juga harus memperhatikan kepentingan masyarakat umum. Sehingga, asas fungsi sosial ditinjau secara yuridis pada prinsipnya menjaga kepastian hukum atas kemanfaatan tanah untuk kepentingan pirbadi, kepentingan sosial dan kepentingan umum, untuk mencapai sebesar-besar kemakmuran rakyat.

\section{Penerapan Asas Fungsi Sosial Hak Atas Tanah di Indonesia}

Berfungsinya sistem hukum menurut Lawrence M. Friedmann dalam tulisannya berjudul “ Legal Culture and Social Development” dalam Jurnal Law and Society, ditentukan antara lain " these are substantive, structure, and cultural (substansi hukum, struktur hukum, dan budaya hukum). Selanjutnya menurut Abdul Manan, yang dimaksud dengan substantif adalah mencakup segala apa yang merupakan keluaran dari suatu sistem hukum. Pengertian ini termasuk norma hukum yang berupa peraturan perundang-undangan, doktrin-doktrin sejauh semuanya itu dipergunakan dalam proses bekerjanya hukum. Struktural hukum adalah mencakup berbagai institusi yang diciptakan oleh sistem hukum dengan berbagai fungsinya dalam rangka mendukung bekerjanya sistem hukum. Budaya hukum adalah keseluruhan faktor yang menentukan bagaimana sistem hukum memperoleh tempatnya dalam masyarakat, sebagai keseluruhan sikap dan sistem nilai yang akan menentukan bagaimana seharusnya hukum itu berlaku dalam masyarakat.

Berdasarkan pendapat tersebut maka untuk mengetahui penerapan asas fungsi sosial hak atas tanah sangat penting untuk meninjaunya dari perspektif substansi hukum, struktur hukum dan budaya hukum pada masyarakat. Hasil penelitian diketahui penerapan asas fungsi sosial hak atas tanah ditinjau dari struktur hukum, diwujudkan dalam berbagai norma hukum untuk melakukan pengendalian pertanahan dan pemberdayaan masyarakat. Norma-norma hukum tersebut antara lain :

1) Undang-Undang Nomor 56 Prp. Tahun 1960 tentang Penetapan Luas Tanah Pertanian, yang merupakan bentuk aturan mengenai Landreform; 
2) Keputusan Presiden Nomor 55 Tahun 1993 tentang Pengadaan Tanah bagi Pelaksanaan Pembangunan untuk Kepentingan Umum.

3) Undang-Undang Nomor 23 tahun 1997 tentang Lingkungan Hidup

4) Undang-Undang Nomor 39 Tahun 1999 tentang Hak Asasi Manusia (HAM) pada Pasal 36 dan 37;

5) Undang Nomor 11 Tahun 2005 tentang Pengesahan International Covenant on Economic, Social, and Cultural Rights (Kovenan Internasional tentang Hak-hak Ekonomi, Social dan Budaya), Pasal 11;

6) Peraturan Presiden Nomor 36 Tahun 2005 tentang Pengadaan Tanah bagi Pelaksanaan Pembangunan untuk Kepentingan Umum

7) Peraturan Presiden Nomor 65 Tahun 2006 tentang Perubahan atas Peraturan Presiden Nomor 36 Tahun 2005 tentang Pengadaan Tanah bagi Pelaksanaan Pembangunan untuk Kepentingan Umum.

8) Undang-Undang Nomor 26 Tahun 2007 tentang Penataan Ruang;

9) Undang-Undang Nomor 41 Tahun 2009 tentang Perlindungan Lahan Pertanian Pangan Berkelanjutan;

10) Peraturan Pemerintah Nomor 11 Tahun 2010 tentang penertiban dan pendayagunaan tanah terlantar;

11) Perkaban Nomor 4 Tahun 2010 tentang Tata Cara Penertiban Tanah Terlantar;

12) Undang-Undang Nomor 2 Tahun 2012 tentang pengadaan tanah untuk kepentingan umum.

Namun berbagai norma hukum yang berkaitan dengan asas fungsi sosial hak atas tanah tersebut dalam penerapannya masih mengalami kendala, akibat :

1) Adanya penafsiran asas "fungsi sosial" hak atas tanah yang bertentangan dengan falsafah dan prinsip dasar UUPA, sehingga menafikan asas keseimbangan antara kepentingan umum dan kepentingan perseorangan. Keadaan ini berdampak terhadap ketidakadilan dalam penguasaan sumbersumber agraria khususnya tanah, pelanggaran HAM terkait hak dasar atas tanah, dan semakin terpinggirkannya hak-hak masyarakat hukum adat.

2) Belum adanya harmonisasi peraturan-peraturan hukum tentang tanah dengan asas fungsi sosial hak atas tanah. Peraturan-peraturan tersebut antara lain :

a) Undang-Undang Nomor 2 Tahun 1960 tentang Perjanjian Bagi Hasil, yang bertentangan dengan prinsip tanah untuk petani dalam Pasal 10 UUPA yang menegaskan tanah pertanian wajib dikerjakan sendiri oleh pemiliknya.

b) Undang-Undang Nomor 56 Prp Tahun 1960 tentang Penetapan Luas Tanah Pertanian, terkait dengan Pasal 7 UUPA yang melarang pemilikan tanah melebihi batas maksimum. 
c) Undang-Undang Nomor 20 Tahun 1961 tentang Pencabutan Hak atas Tanah dan Benda-benda Yang Ada Di Atasnya. Sebenarnya aturan ini sudah ada dalam Undang-Undang Nomor 2 Tahun 2012 tentang Pengadaan Tanah Bagi Pembangunan Untuk Kepentingan Umum namun kedudukan undang-undang ini dikaburkan karena tidak disinggung di dalamnya.

d) Undang-Undang Nomor 26 tahun 2007 tentang Penatan Ruang, aturan ini diterjemahkan dalam Rencana Tata Ruang Wilayah (RTRW) Kota/Kabupaten. Penataan ruang melalu Peraturan Daerah RTRW masih belum mampu memenuhi prinsip-prinsip hukum agraria khususnya fungsi sosial hak atas tanah dan belum sepenuhnya mengakomodasi kepentingan ketahanan dan kedaulatan pangan.

e) Undang-Undang Nomor 2 Tahun 2012 tentang Pengadaan Tanah Bagi Pembangunan Untuk Kepentingan Umum. Undang-undang ini sangat pragmatis apabila ditinjau dari asas fungsi sosial hak atas tanah. Prinsip musyawarah yang menjadi dasar dalam proses pengadaan tanah untuk kepentingan umum seringkali dirasakan tidak mampu menghasilakn keputusan yang adil bagi masyarakat, terutama keberatan yang diajukan akibat tidak sesuainya nilai ganti rugi atau penggantian tanah.

Selanjutnya penerapan asas fungsi sosial hak atas tanah ditinjau dari struktur hukum, diketahui dari peran pemerintah dalam melaksanakan kewajiban mengatur penggunaan, peruntukan dan persediaan tanah untuk kepentingan rakyat, bangsa dan negara. Hasil penelitian diketahui peran pemerintah antara lain :

1) Pemerintah dalam hal ini BPN mengeluarkan kebijakan yang berupaya untuk menjamin keseimbangan antara kepentingan perorangan, kepentingan sosial, dan kepentingan umum atas tanah. Antara lain melalui, redistribusi tanah, penertiban tanah terlantar, legalisasi asset tanah bagi masyarakat tidak mampu, dan ganti rugi yang layak dalam proses pengadaan tanah untuk kepentingan umum.

2) Pengendalian pertanahan dengan memberikan perlindungan hak-hak warga negara atas tanah, melalui program reforma agraria, dengan melaksanakan asset reform dan akses reform khususnya bagi rakyat tidak mampu dan petani. 
3) BPN melalui Kantor Pertanahan di daerah melakukan proteksi tanah-tanah pertanian yang kebijakannya bekerjasama dengan Pemda, mengaju pada Rencana Tata Ruang dan Wilayah (RTRW) ditiap-tiap daerah.

4) Pemberdayaan masyarakat, melalui pembentukan Pokmasdartibnah (Kelompok Masyarakat Sadar Tertib Pertanahan), untuk membentuk kesadaran masyarakat tentang pentingnya menjaga tanah dalam fungsi sosial.

Namun peran pemerintah dalam menerapan asas fungsi sosial hak atas tanah masih mengalami kendala akibat :

1) Kurangnya fungsi pengendalian pertanahan dan pemberdayaan masyarakat, akibat belum terintegrasinya fungsi pengaturan dalam bidang pertanahan antara pusat dan daerah.

2) Kurangnya kesadaran para para penegak hukum dalam urusan pertanahan untuk melaksanakan peran penguasaan hak atas tanah, terhadap prinsip asas fungsi sosial hak atas tanah, menyebabkan adanya berbagai kebijakan yang melanggar dan merugikan masyarakat.

3) Seringkali proses pengadaan tanah untuk kepentingan umum yang merugikan masyarakat, akibat proses ganti rugi yang cenderung memaknai tanah sebagai asset ekonomi semata bukan sebagai hak rakyat.

4) Pemberdayaan masyarakat selama ini hanya terkesan untuk memenuhi kepentingan administrasi pertanahan, kurang memperhatikan prinsip landreform dalam memanfaatkan tanah untuk sebesar-besar kemakmuran rakyat.

Dari tinjauan budaya hukum penerapan asas fungsi sosial hak atas tanah adalah bahwa inti dan arti penegakan hukum terletak pada kegiatan menyerasikan hubungan nilai-nilai yang terjabarkan di dalam kaidah-kaidah dan mengejawantah sikap, untuk menciptakan, memelihara dan mempertahankan kedamaian pergaulan hidup (Soerjono Soekanto, 2011: 5).

Menurut Husendro Penyelidik Senior Komisi Nasional Hak Asasi Manusia (Komnas HAM RI), menyatakan bahwa penerapan asas fungsi sosial hak atas tanah berkaitan dengan pemenuhan prinsip hak asasi manusia (HAM). Asas fungsi sosial hak atas tanah mengandung dua substansi Pertama, kepentingan umum harus diutamakan diatas kepentingan individu, hal ini terjadi manakala ada perbenturan antara kepentingan umum dan kepentingan individu, maka yang 
diutamakan adalah kepentingan umum namun harus memperhatikan juga aspek kepentingan individu, karena hak atas tanah dijamin oleh undang-undang bagi tiap-tiap warga negara. Kedua, setiap orang yang menguasai tanah harus menghormati hak-hak orang lain, tidak boleh merugikan orang lain dan menelantarkannya. Intinya penerapan asas fungsi sosial hak atas tanah didasari prinsip keadilan, solidaritas, prinsip nasionalisme, dan prinsip gotong royong dalam mengusahakan tanah.” (Reduksi Data, tanggal 04/01/2013).

Akibat adanya pengaruh modernisasi maka dalam pengelolaan tanah terjadi pergeseran nilai-nilai sosial budaya. Timbul berbagai perilaku yang tidak mematuhi hukum yang menimbulkan permasalahan dalam menerapkan asas fungsi sosial hak atas tanah. Perilaku-perilaku tersebut antara lain :

a. Masih banyaknya orang-orang yang menelantarkan tanah;

b. Perilaku tamak dan serakah dalam memiliki tanah sehingga banyak terjadi penguasan-penguasaan tanah yang luas tanahnya melebihi batas aturan minimum dan maksimum kepemilikan tanah dan tanah absente;

c. Kecenderungan orang melakukan alih fungsi tanah pertanian menjadi non pertanian;

d. Pemanfaatan tanah yang tidak memperhatikan fungsi ekologi tanah dan menimbulkan kecenderungan kerusakan tanah;

e. Melunturnya perilaku gotong-royong dalam pemanfaatan tanah untuk memenuhi kebutuhan hidup rakyat;

f. Memanfaatkan tanah hanya untuk mencari keuntungan ekonomi semata tanpa memperhatikan kepentingan tanah yang berkelanjutan (sustainable).

Untuk menerapkan asas fungsi sosial hak atas tanah diperlukan upaya adanya pemberdayaan pada masyarakat agar memiliki kesadaran dalam mematuhi asas fungsi sosial hak atas tanah. Dari hasil penelitian diperoleh contoh penerapan asas fungsi sosial hak atas tanah yang terintegrasi dengan pemberdayaan dan pendidikan hukum pada masyarakat. Pembentukan kesadaran hukum merupakan bagian dari kegiatan pemberdayaan masyarakat baik yang dilakukan oleh pemerintah maupun organisasi atau lembaga swadaya masyarakat.

Melalui kebijakan pemerintah diketahui upaya untuk membentuk kesadaran hukum tanah pada masyarakat terwujud dalam program pemberdayaan masyarakat yang dilakukan oleh Badan Pertanahan Nasional (BPN) melalui 
Kantor Pertanahan di tiap-tiap daerah. BPN melakukan kegiatan yang bertujuan untuk melakukan pemberdayaan masyarakat, agar mampu membangkitkan kesadaran akan potensi yang dimiliki dan mengembangkan kemampuan untuk memperoleh akses atas sumber-sumber agraria untuk meningkatkan taraf hidup dan kesejahteraan. Untuk lebih mampu memberdayakan masyarakat BPN membentuk kelompok-kelompok masyarakat dalam bentuk Kelompok Masyarakat Sadar Tertib Pertanahan (Pokmadartibnah). Gerakan masyarakat sadar pertanahan sudah dibentuk sejak tahun 1995 dengan Keputusan Menteri Negara Agraria Nomor 5 Tahun 1995 tentang Gerakan Nasional Sadar Tertib Pertanahan.

Pokmasdartinah menjadi stimulus yang dapat mendukung pencapaian tujuan pengelolaan pertanahan oleh BPN RI. Ruang lingkup kegiatan yang dilaksanakan oleh Pokmasdartinah antara lain:

1) Mengikuti secara aktif pelaksanaan kegiatan Reforma Agraria dan program pertanahan lainnya;

2) Memberikan saran terhadap penyelenggaraan kegiatan agar pelaksanaannya efektif dan efisien untuk mencapai sasaran;

3) Membangun kebersamaan dalam memperoleh akses penguatan, pemanfaatan, peruntukan dan penggunaan tanah, permodalan dan peningkatan produksi serta pemasaran.

4) Meningkatkan peran dan pendayagunaan tanah. Meliputi : pemanfaatan, peruntukan penggunaan, kelestarian lingkungan hidup, penguatan hak tanah, penanganan dan pencegahan timbulnya konflik, sengketa dan masalah pertanahan.

Tujuan dari dibentuknya Pokmasdartibnah adalah untuk meningkatkan partisipasi masyarakat dalam penyelenggaraan Program Pembaharuan Agraria Nasional (PPAN) dan Program Pertanahan lainnya untuk mewujudkan sasaran Catur Tertib Pertanahan (Tertib Hukum Pertanahan, Tertib Administrasi Pertanahan, Tertib Penggunaan Tanah, Tertib Pemeliharaan Tanah dan Lingkungan Hidup).

Sebagai salah satu contoh Pokmasdartinah yang telah berupaya menerapkan kebijakan pertanahan berdasarkan asas fungsi sosial hak atas tanah adalah Pokmasdartibnah "SITI MAKMUR" di Kabupaten Sukoharjo, yang telah 
terbentuk sejak tanggal 03 November 2007 berdasarkan Surat Keputusan Kepala Desa Kedungsonoo, Kecamatan Bulu Nomor 593 / 10/ 2007. Pokmasdartibnah merupakan Lembaga Sosial Kemasyarakatan binaan Kantor Pertanahan di Kabupaten Sukoharjo pada Seksi Pengendalian dan Pemberdayaan Kantor Pertanahan Kabupaten Sukoharjo.

Menurut keterangan dari Kepala Sub Seksi Pengendalian Tanah Kantor Pertanahan Kabupaten Sukoharjo Kusmanto, pembentukan Pokmasdartinah sebagai salah satu upaya untuk membentuk kesadaran masyarakat tentang urusan pertanahan, terutama berkaitan dengan pengetahuan masyarakat tentang pertanahan dan aspek yang melingkupinya, seperti aspek ekonomi, sosial dan budaya. Pokmasdartinah "SITI MAKMUR" di Desa Kedungsono merupakan desa yang ditunjuk sebagai pelaksana kegiatan reforma agraria pada Kantor Pertanahan Kabupaten Sukoharjo, karena desa ini merupakan desa lokasi kegiatan PRONA (Proyek Nasional) dan masyarakatnya berekonomi lemah. Pembentukan Pokmasdartinah ini juga merupakan perwujudan dari penerapan asas fungsi sosial hak atas tanah yang merupakan kewajiban yang harus dilaksanakan menurut UUPA (Reduksi tanggal 20/9/2013).

Ditegaskan oleh Kusmanto, bahwa tanah itu memiliki fungsi sosial yang sangat berkaitan dengan kesumberdayaan. Kesumberdayaan masyarakat itu bermula sebuah pemikiran bahwa masyarakat itu selalu berhubungan dengan tanah. Walau sebelumnya hubungannya hanya semata-mata terbatas pada hubungan yuridis, namun yang lebih penting lagi adalah hubungan sosial yang terbentuk dalam konteks peningkatan ekonomi masyarakat berkaitan dengan sumber daya alam tanah yang dimiliki. Untuk memenuhi fungsi sosial tanah selama ini Kantor Pertanahan melaksanakan 2 strategi melalui penerapan asset reform dan akses reform. Aset reform, yaitu penguatan aset masyarakat yang belum memiliki sertifikat. Aset reform/penguatan aset, dilakukan dengan menyusun langkah awal melalui pendatangan ke desa-desa, prioritasnya daerahdaerah marginal, pinggiran. Asumsinya karena pertama, tingkat kesadaran hukumnya kurang, kedua, proses peralihan hak relatif lebih rendah volumenya dibanding di kota, ketiga, nilai-nilai tanahnya masih rendah nilai jualnya. Setelah memiliki data dari pemerintah desa tentang berapa tanah-tanah di desa yang belum bersertifikat selanjutnya diinventaris dijadikan acuan bagi pemerintah 
dalam menentukan program-program. Program pemerintah tersebut antara lain PRONA, yakni program nasional agraria dari pusat, PRODA dari kabupaten yang pendanaannya melalui APBD. Sedangkan Akses reform, akses reform itu bagaimana masyarakat ketika sudah memiliki sertifikat memiliki akses secara ekonomi. "Akses reform, merupakan tindak lanjut dari aset reform, setelah mendapatkan penguatan aset berupa sertifikat, BPN berupaya untuk memberikan pemahaman kepada penerima sertifikat, serta memberi motivasi bagaimana masyarakat setelah mendapat sertifikat, sehingga tanah yang telah bersertifikat tersebut secara signifikan bisa meningkatkan usaha ekonomi mereka. Terkait dengan kedua prioritas BPN tersebut dilaksanakan dengan dukungan dari Instansi yang terkait seperti Dinas Pertanian, Perdagangan, PU dan Kantor bagian hukum. Kantor Hukum terkait dengan muatan asset reform dan kepastian hak atas tanah, sedangkan untuk akses reform didukung dengan berbagai program kegiatan dari Dinas Pertanian. Kegiatan Pokmasdartinah "SITI MAKMUR” mengembangkan model melalui usaha budidaya ternak kambing, budidaya jamur dan budidaya tanaman empon-empon. Kantor Pertanahan juga melakukan kerjasama dengan perbankan salah satunya BRI yang memberikan pinjaman modal usaha bagi peserta budidaya, selain itu juga melibatkan pihak pengembang usaha untuk memberikan pelatihan budidaya. (Reduksi data tanggal 20/9/2013).

Ada 2 kegiatan yang menjadi sasaran atau target Pokmasdartinah "SITI MAKMUR", yakni :

1) Tanah sebagai bagian dari sumber daya alam atau diistilahkan sebagai sumber daya agraria dapat memperoleh kepastian hak hukum.

2) Sumber daya Manusia dalam hal ini anggota kelompok Pokmasdartibnah "SITI MAKMUR", mampu menerapkan prinsip keseimbangan antara kepentingan umum, perorangan dan masyarakat, terkait aspek ekonomi, sosial, budaya masyarakat.

Pembentukan Pokmasdartinah merupakan sarana dalam menerapkan fungsi sosial hak atas tanah untuk memenuhi prinsip asset dan akses reform tanah. Strateginya melalui pengembangan model dalam meningkatkan fungsi tanah yang sebelumnya hanya dipahami sebagai asset dari masyarakat yang hanya membutuhkan kepastian hukumnya saja dikembangkan menjadi fungsi sebagai akses dalam memenuhi kebutuhan masyarakat yang bersifat sosial. 
Selain oleh pemerintah, organisasi atau lembaga swadaya masyarakat juga telah ikut berpartisipasi dalam melakukan penerapan asas fungsi sosial hak atas tanah yang terintegrasi dengan pemberdayaan dan pendidikan hukum pada masyarakat. Salah satunya adalah kegiatan yang telah dilakukan oleh Konsorsium Pembaharuan Agraria (KPA), sebagai suatu organisasi yang mengkampanyekan pembaharauan agraria (reforma agraria). KPA berupaya untuk menciptanya sistem agraria yang adil, pemerataan pengalokasian sumber-sumber agraria bagi seluruh rakyat Indonesia, dan adanya jaminan penguasaan, pemilikan dan pengelolaan sumber-sumber agraria bagi petani, nelayan, buruh dan masyarakat adat, serta adanya jaminan kesejahteraan bagi rakyat miskin.

KPA telah melakukan kegiatan yang salah satu program kerjanya adalah pembentukan Desa Maju Reforma Agraria (Damara). Pembentukan Desa Damara berupaya untuk mentransformasikan desa dalam konsep reforma agraria, yakni penguasaan tanah sebagai sumber agraria yang mampu mendatangkan kesejahteraan seluruh rakyat terutama petani.

Menurut keterangan dari Sekretaris Jenderal (Sekjen) Konsorsium Pembaharuan Agraria (KPA) Iwan Nurdin (Data Reduksi tanggal 29/09/2013), Desa Damara dilatarbelakangi oleh berbagai persoalan yang ada di masyarakat terutama masyarakat yang berada di pedesaan, antara lain :

1) Tingkat pengangguran di pedesaan tinggi, karena kalangan muda tidak tertarik terjun ke dunia pertanian. Ini terkait dengan dunia pendidikan yang mengucilkan potensi besar dunia kerja di bidang pertanian dan sistem ekonomi nasional yang sangat diskrimatif kepada sektor pertanian.

2) Ketimpangan struktur agraria khususnya kepemilikan tanah di pedesaan. Ini disebabkan banyaknya tanah-tanah pertanian di pedesaan telah jatuh keepemilikannya di tengan para orang kaya. Kecenderungan keadaan yang semacam ini terus meningkat karena sistem bagi hasil pertanian yang tidak diatur secara adil sehingga sangat menguntungkan orang kaya pemilik tanah. Faktor lainnya adalah tidak berjalannya beberapa peraturan seperti larangan tanah absentee dan larangan kelebihan maksimum kepemilikan tanah pertanian. Ketimpangan semacam ini semakin diperkuat oleh maraknya tanah sebagai alat investasi dan spekulasi yang menguntungkan. 
3) Teknologi sarana produksi pertanian (saprodi) seperti bibit, pupuk dan pestisida dikuasai oleh para pengusaha. Sementara keahlian pertanian organik yang bisa menghasilkan saprodi secara mandiri semakin hilang. Selanjutnya, penguasaan teknologi pengolahan pasca panen pada petani juga tidak berkembang. Jaringan pemasaran produk pertanian dan hasil olahan milik petani sangat terbatas dan tidak dikembangkan.

4) Secara makro kebijakan baik di tingkat nasional dan wilayah tidak ada usaha untuk menyelesaikan persoalan di atas secara komprehensif. Orientasi kebijakan baik dalam hal penyediaan tanah, saprodi, teknologi pengolahan dan pemasaran lebih ditujukan untuk dikuasai oleh investor besar. Keadaan diatas akan semakin memperparah persoalan utama yang telah diungkapkan di atas.

Selain latar belakang tersebut diatas KPA (Data Reduksi tanggal 29/09/2013) sebagai inisiator program Desa Damara memiliki semangat untuk melakukan upaya untuk "Membangun Desa". KPA menginisiasi setiap desa mengembangkan sebuah badan usaha bersama milik desa dan badan usaha bersama milik petani dengan fondasi yang kokoh yang berbentuk koperasi bisa juga perusahaan. Dalam pelaksanaannya setiap desa di bagi dalam kewilayahan yang lebih kecil (dukuh/dusun), dan setiap dusun dibagi dalam unit produksi pertanian. Usaha yang dikembangkan adalah usaha pertanian semi modern, seperti peternakan dan penggemukan sapi.

Untuk melakukan usaha pertanian menurut Iwan Nurdin (Data Reduksi tanggal 29/09/2013), dikembangkan pertanian secara bersama, dimana setiap dusun biasanya mempunyai petani yang memiliki luasan lahan yang berbedabeda, namun kepemilikan mereka saling berdekatan dan dibatasi dengan pematang. Setiap 10 sampai 15 hektar, sawah-sawah dipetakan kembali. Bisa juga setiap 15 belas petani dikumpulkan dalam sebuah unit produksi. Setiap petani mempunyai jumlah jam kerja pada hamparan sama, sehingga setelah panen, jumlah jam kerja dan saham menjadi dasar perolehan hasil panen. Sebagai dasar ujicoba bisa dilakukan pemakaian lahan hanya untuk musim tanam palawija. Insiatif lainnya melalui penyewaan lahan oleh unit usaha dimana anggotanya adalah pemuda atau buruh tani pada sawah yang tidak dikelola saat musim palawija. Unit produksi lainnya yakni peternakan dan perikanan, selanjutnya yang layak dikembangkan untuk mendukung usaha tersebut adalah usaha pakan ternak 
mandiri dimana unit usaha peternak tersebut sangat membutuhkan pakan. Unit produksi desa yang terbetuk akan diperkuat dengan bantuan kepada petani berupa permodalan bisa dilakukan dengan dana bergulir dari APBD setempat. Selanjutnya, permodalan dapat diperoleh dengan menjamin kredit dan mensubsidi bunga kredit bagi unit usaha bersama petani. Selain itu perlu adanya peraturan bagi hasil produk pertanian yang mendorong para pemilik tanah absentee dan kelebihan tanah melepas tanahnya. Aturan tersebut bisa diperkuat melalui PERDA di tiap-tiap daerah yang harapannya akan mendorong tercapainya kesadaran masyarakat untuk terwujudnya usaha pertanian bersama atas dasar keadilan agraria.

Menurut Iwan Nurdin (Data Reduksi tanggal 29/09/2013), Desa Damara merupakan program yang saat ini sedang diupayakan penerapannya diberbagai daerah dampingan KPA yang berangkatnya dari berbagai konflik yang diakibatkan adanya ketidakadilan dalam penguasaan sumber-sumber agraria. Melalui terwujudnya Desa Damara diharapkan desa-desa yang sedang berkonflik agraria, salah satunya di Desa Pasawahan, Kecamatan Banjarsari, Kabupaten Ciamis, Provinsi Jawa Barat, agar mampu dengan kemandiriannya mengupayakan menyelesaikan berbagai persoalan yang timbul akibat terjadinya konflik agraria dan memiliki kesadaran untuk melakukan usaha atas sumber daya agrarian yang berkeadilan.

Desa Damara ini merupakan wujud dari penerapan asas fungsi sosial hak atas tanah. Kegiatan yang dilakukan berorientasi pada pemanfaatan tanah untuk usaha bersama dan untuk meningkatkan kesejahteraan secara merata bagi rakyat dengan mengusahan tanah untuk kegiatan produksi pertanian. Kebersamaan dalam melakukan usaha pertanian merupakan bentuk penerapan asas fungsi sosial hak atas tanah di masyarakat.

Penerapan asas fungsi sosial hak atas tanah mengandung prinsip penggunaan tanah yang tidak merugikan kepentingan perorangan, kepentingan sosial, dan kepentingan umum atas tanah. Setiap orang dan badan hukum yang mempunyai sesuatu hak atas tanah pertanian diwajibkan mengerjakan atau mengusahakan sendiri secara aktif, dengan mencegah cara-cara pemerasan. Selain itu memelihara tanah, termasuk menambah kesuburannya serta mencegah kerusakannya adalah kewajiban tiap-tiap orang, badan hukum atau instansi yang 
mempunyai hubungan hukum dengan tanah itu, dengan memperhatikan pihak yang ekonomis lemah. Kegiatan ini akan terlaksana dengan baik, dengan adanya kesadaran masyarakat bahwa tanah memiliki fungsi sosial untuk memenuhi sebesar-besar kemakmuran rakyat. Kesadaran yang dibentuk, melalui pengetahuan tentang pentingnya tanah berperspektif fungsi sosial hak atas tanah dalam memenuhi tujuan reforma agraria dan pendidikan usaha ekonomi untuk menjaga keberlanjutan tanah sebagai faktor produksi manusia. Kegiatan yang telah dilakukan oleh pemerintah maupun Konsorsium Pembaharuan Agraria (KPA) tersebut diatas merupakan bentuk pendidikan bagi masyarakat yang bertujuan untuk membentuk kesadaran reforma agraria yang didalamnya mengandung prinsip asas fungsi sosial hak atas tanah.

\section{Simpulan}

Secara teori asas fungsi sosial hak atas tanah pada hakekatnya mengandung makna adanya pengakuan atas kepentingan perorangan, kepentingan sosial dan kepentingan umum atas tanah berdasarkan prinsip reforma agraria dan hak asasi manusia (HAM). Asas fungsi sosial hak atas tanah memberi kewenangan kepada pemilik hak untuk mempergunakan kepemilikan atas tanah dalam batas-batas yang ditentukan oleh hukum, dengan memperhatikan kepentingan masyarakat dan negara.

Landasan yuridis asas fungsi sosial hak atas tanah, didasarkan pada Pasal 6 UUPA yang merupakan pencerminan dari ketentuan Pasal 33 ayat (3) UUD NRI Tahun 1945 sebagai ketentuan yang menegaskan pentingnya perlindungan tanah bagi sebesar-besar kemakmuran rakyat. Selain itu juga dilandasi Pasal $28 \mathrm{H}$ ayat (4) UUD NRI Tahun 1945, Undang-Undang Nomor 39 Tahun 1999 tentang Hak Asasi Manusia (HAM) pada Pasal 36 ayat (1) dan 37 ayat (1), serta Pasal 11 ayat (1) Undang-Undang Nomor 11 Tahun 2005 tentang Pengesahan International Covenant on Economic, Social, and Cultural Rights (Kovenan Internasional tentang Hak-hak Ekonomi, Social dan Budaya). Asas fungsi sosial hak atas tanah mengandung prinsip yang diwujudkan dalam berbagai norma hukum untuk memberikan pengakuan hak atas tanah, yang menjamim kemanfaatan tanah baik sebagai social asset dan capital asset berdasarkan Pancasila. 
Secara substansi hukum asas fungsi sosial hak atas tanah diwujudkan dalam berbagai norma hukum, walaupun secara khusus tidak ada namun dijabarkan dalam berbagai aturan tentang landreform, konsolidasi tanah, redistribusi tanah, penertiban tanah-tanah terlantar, dan pengadaan tanah untuk kepentingan umum. Secara struktur hukum asas fungsi sosial hak atas tanah telah diterapkan melalui berbagai kebijakan pemerintah dalam hal ini BPN, untuk melakukan pengendalian pertanahan yang menjamin keseimbangan antara kepentingan perorangan, kepentingan sosial, dan kepentingan umum atas tanah melalui. Pengendalian pertanahan dengan memberikan perlindungan hak-hak warga negara atas tanah, melalui program reforma agraria, dengan melaksanakan asset reform dan akses reform khususnya bagi rakyat tidak mampu dan petani. Penerapan asas fungsi sosial dalam tinjauan budaya hukum, telah dilakukan upaya pemberdayaan masyarakat melalui pembentukan Pokmasdartibnah (Kelompok Masyarakat Sadar Tertib Pertanahan) oleh BPN, untuk membentuk kesadaran masyarakat tentang pentingnya menjaga tanah sebagai fungsi sosial. Selain itu juga adanya partisipasi masyarakat dari Konsorsium Pembaharuan Agraria (KPA) dengan membentuk Desa Damara yang memiliki kesadaran untuk melakukan usaha atas sumber daya agraria yang berkeadilan. Pembentukan Pokmasdartibnah maupun Desa Damara merupakan wujud dari penerapan asas fungsi sosial hak atas tanah yang berorientasi pada pemanfaatan tanah sebagai social asset dan capital asset untuk sebesar-besar kemakmuran bersama. Penerapan asas fungsi sosial hak atas tanah terwujud apabila (1) tanah bisa memberikan manfaat bagi rakyat; (2) tercapaianya pemerataan dalam pemanfaatan tanah; (3) adanya partisipasi rakyat dalam memelihara kemanfaatan tanah; dan (4) perlindungan hak-hak warga negara atas tanah berdasarkan prinsip hak asasi manusia. Kemanfaatan tanah bagi sebesarbesar kemakmuran rakyat akan terwujud pada negara yang pemerintah dan warga negaranya memiliki kesadaran hukum untuk mentaati asas fungsi sosial hak atas tanah.

\section{E. Saran}

Sangat penting untuk mensosialisikan pemahaman asas fungsi sosial hak atas tanah lebih lanjut agar tidak hanya dimaknai sebagai dasar hukum atas penggunaan tanah untuk kepentingan umum, namun juga termaknai sebagai perlindungan penggunaan tanah untuk kepentingan perorangan dan kepentingan 
sosial atas tanah. Sebaiknya pemahaman tanah sebagai social asset dan capital asset menjadi faktor penting yang harus diketahui oleh warga negara. Sebaiknya asas fungsi sosial hak atas tanah menjadi pengetahuan bagi warga negara agar terjamin hak-haknya sebagai warga negara, oleh karena itu penting adanya sosialisasi maupun pendidikan pada masyarakat yang bertujuan untuk membentuk kesadaran hukum untuk menerapkan fungsi sosial hak atas tanah bagi warga negara.

\section{Daftar Pustaka}

Ben Mc Farlane. 2008. The Structure of Property Law. Oxford: Hart Publishing. Dixon, Martin. 2004. Principles of Land Law. London : Cevendish Publishing Limited

Erwin. Muhamad. 2011. Filsafat Hukum : Reflektif Kritis terhadap Hukum. Jakarta : Raja Grafindo Persada.

Limbong, Bernhard. 2011. Pengadaan Tanah Untuk Pembangunan, Regulasi, Kompensasi, Penegakan Hukum. Jakarta : Pustaka Margatetha.

Limbong, Bernhard. 2011. Hukum Agraria Nasional. Jakarta : Pustaka Margatetha

Limbong, Bernhard. 2012. Konflik Pertanahan. Jakarta : Margaretha Pustaka.

Miles, Matthew B. and Huberman, A Micheal. 1984. Qualitative Data Analysis, A Sourcebook of New Methods. Beverlly Hills CA : Sage Publications, Inc.

Nickel, James.W. (1996). HAM Making Sense of Human Right. Jakarta: Gramedia Pustaka Utama,

Nurdin, Iwan, dkk. 2014. Siaran Pers Penyelesaian Konflik Agraria Wajib Jadi Prioritas Jokowi-JK. Komisi Nasional Hak Asasi Manusia (Komnas HAM), Konsorsium Pembaruan Agraria (KPA), dan Wahana Lingkungan Hidup Indonesia (WALHI), Jakarta

Parlindungan, AP. 1991. Komentar atas Undang-Undang Pokok-Pokok Agraria. Bandung : Mandar Maju

Riyanto. Astim. 2009. Kapita Selekta Hukum Konstitusi. Bandung : YAPEMDO

Rubaie, Achmad. 2007. Hukum Pengadaan Tanah untuk Kepentingan Umum. Malang: Bayumedia

Sitorus, Oloan dan Sierrad, Zaki. 2006. Hukum Agraria Konsep Dasar dan Implementasi. Yogyakarta : Mitra Kebijakan Tanah Indonesia

Soemitro, RH. 1998. Metode Penelitian Hukum dan Yurimetri. Jakarta : Ghalia

Sumardjono, Maria S.W. 2007. Alternatif Kebijakan Pengaturan Hak Atas Tanah Beserta Bangunan. Jakarta : Kompas

Suratman, Dillah. Phillips. 2013. Metode Penelitian Hukum, Dilengkapi Tata Cara \& Contoh Penulisan Karya Ilmiah Bidang Hukum. Bandung : Alfabeta.

\section{Jurnal:}

Foster, Sheila and Bonilla, Daniel, The Social Function of Property: A Comparative Law Perspective (November 15, 2011). Fordham Law Review, 
Vol. 80, p. 101, 2011; Fordham Law Legal Studies Research Paper No. 1960022. Available at SSRN: http://ssrn.com/abstract=1960022

Friedmann, M, Lawrence. 1986. Legal Culture and Social Development. dalam Law and Society, Vol. 4, No. 1, Issue Stable URL: http://www.jstor.org/stable/i354468

\section{Internet:}

$\begin{array}{llll}\text { Nobleman, } & \text { Eli, } & \text { E., } & 1961 \quad \text { 195-196, }\end{array}$ http://www.wcl.american.edu/journal/lawrev/10/nobleman.pdf, dikutip pada 26 Mei 2014 